\title{
Mikrolevät lypsylehmien ruokinnassa: 1. Maidontuotanto
}

Anni Halmemies-Beauchet-Filleau, Marjukka Lamminen, Tuomo Kokkonen, Seija Jaakkola ja Aila Vanhatalo

Helsingin yliopisto, Maataloustieteiden laitos, PL 28, 00014 Helsingin yliopisto, etunimi.sukunimi@helsinki.fi

\section{TIIVISTELMÄ}

Mikrolevät ovat mikroskooppisen pieniä yksisoluisia eliöltä. Ne kasvavat nopeasti muuntaen valon energiaa ja hiilidioksidia runsaasti valkuaista ja välttämättömiä omega-rasvahappoja sisältäväksi biomassaksi. Mikrolevistä lypsylehmien valkuaisrehuna on vähän tutkimustietoa. Tässä tutkimuksessa selvitettiin mikrolevien vaikutusta lypsylehmien rehun syöntiin, maidontuotantoon ja maidon rasvahappokoostumukseen rypsiin ja soijaan verrattuna. Viikin opetus- ja tutkimustilan navetassa tehtiin kaksi ruokintakoetta osana EAKR:n rahoittamaa Algae Foods -projektia. Kokeessa 1 oli 8 ay-lehmää, joiden poikimisesta oli kokeen alkaessa 186 pv. Koemallina oli toistettu $4 \times 4$ latinalainen neliö. Kontrolliruokinnassa lehmät saivat väkirehuna vilja-leikeseosta ilman valkuaislisää. Isonitrogeenisinä vilja-leikkeen valkuaistäydennyksinä olivat rypsirouhe, Spirulina platensis-leväjauho tai näiden seos vastaten 2,5 kg:n rypsirouheannosta/pv. Väkirehuannos oli $12 \mathrm{~kg} / \mathrm{pv}$. Kokeessa 2 oli 4 ay-lehmää, joiden poikimisesta oli 112 pv. Koemallina oli 4x4 latinalainen neliö. Isonitrogeenisinä vilja-leikeseoksen valkuaistäydennyksinä olivat soijarouhe, Spirulina platensis, Chlorella vulgaris sekä Chlorella vulgariksen ja Nannochlorpsis gaditanan seos vastaten 1,8 kg:n soijarouheannosta/pv. Väkirehuannos oli 12,5 kg/pv. Molemmissa kokeissa lehmät saivat nurmisäilörehua vapaasti. Valkuaistäydennys lisäsi suuntaa-antavasti eläinten säilörehun syöntiä $(+0,80 \mathrm{~kg} \mathrm{ka} / \mathrm{pv})$ ja energiakorjattua maitotuotosta $(+0,97 \mathrm{~kg} / \mathrm{pv}$; koe 1$)$. Mikrolevät, etenkin Nannochloropsis, heikensivät väkirehun maittavuutta perinteisiin valkuaisrehuihin verrattuna. Lehmät kuitenkin kompensoivat vähäisempää väkirehun syöntiä lisäämällä säilörehun syöntiä, joten koko dieetin kuiva-aineen syönneissä ei ollut eroa koeruokintojen välillä (koe 1 keskimäärin $23,0 \mathrm{~kg} \mathrm{ka} / \mathrm{pv}$, koe 2 keskimäärin $21,5 \mathrm{~kg} \mathrm{ka} / \mathrm{pv}$ ). Rypsin tai soijan korvaaminen mikrolevällä ei vaikuttanut maitotuotokseen (koe 1 keskimäärin 27,3 kg/pv, koe 2 keskimäärin 30,6 kg/pv). Rypsi- ja Spirulina-ruokintojen välillä ei ollut eroa maidon rasvapitoisuudessa eikä rasvatuotoksessa (koe 1). Sen sijaan soijan korvaaminen mikrolevällä lisäsi maidon rasvapitoisuutta $(+0,19 \%$-yksikköä; koe 2). Spirulinaruokinta lisäsi maidon rasvapitoisuutta ja -tuotosta Chlorella-ruokintoihin verrattuna $(+0,32 \%$-yksikköä, $+210 \mathrm{~g} / \mathrm{pv}$; koe 2). Rypsin lipidit sisälsivät runsaasti cis-9 18:1-rasvahappoa (43 \% rasvahapoista), soijan 18:2n-6 (50 \%), Spirulinan 16:0 ja 18:3n-6 (46 \%, $20 \%)$, Chlorellan 18:2n-6 (49 \%) ja Nannochloropsiksen cis-9 16:1 ja 20:5n-3 (EPA) (36\%, $19 \%$ ). Erot mikrolevien rasvahappokoostumuksessa heijastuivat maitorasvaan. Spirulina lisäsi maitorasvan 18:3n-6-pitoisuutta ja Chlorella 18:2n-6pitoisuutta. Nannochloropsiksen lisääminen Chlorella-ruokintaan kolminkertaisti maitorasvan EPA-pitoisuuden (0,07 vs. 0,21\% rasvahapoista). Kaiken kaikkiaan muutokset maitorasvan koostumuksessa olivat kuitenkin pieniä, sillä tutkitut valkuaisrehut sisälsivät suhteellisen vähän lipidejä (alle $40 \mathrm{~g} / \mathrm{kg} \mathrm{ka}$ rasvahappoja). Tulosten perusteella mikrolevien maidontuotanto-ominaisuudet vastaavat rypsiä ja soijaa lypsylehmien nurmisäilörehu-viljapohjaisessa ruokinnassa.

\section{ASIASANAT}

Lypsylehmä, mikrolevä, valkuainen, rypsi, soija, maitorasva, omega-3 


\section{JOHDANTO}

Eläinten ruokinnassa käytettävien perinteisten valkuaisrehujen saatavuus ja hinta ovat tulevaisuudessa yhä epävarmempia maailman väestön lisääntyessä, luonnonvarojen ehtyessä ja ilmastonmuutoksen edetessä. Mikrolevät ovat mikroskooppisen pieniä, yksisoluisia eliöltä. Ne kasvavat nopeasti muuntaen valon energiaa ja hiilidioksidia runsaasti valkuaista ja välttämättömiä omega-rasvahappoja sisältäväksi biomassaksi (Becker 2007, Lang ym. 2011). Mikroleviä voidaan myös tuottaa alueilla, jotka eivät sovellu rehu- ja ruokakasvien viljelyyn (Mata ym. 2010). Mikrolevävalkuainen sisältää kuitenkin tyypillisesti soija- ja rypsivalkuaista vähemmän histidiiniä (Becker 2007, Luke 2015), joka on lypsylehmien maidontuotantoa ensimmäisenä rajoittava aminohappo viljaan ja nurmisäilörehuun pohjautuvassa ruokinnassa (Vanhatalo ym. 1999, Huhtanen ym. 2002). Lisäksi mikrolevien maittavuus saattaa olla perinteisiä rehuja huonompi, mikä voi vähentää kuiva-aineen syöntiä (Franklin ym. 1999, Drewery ym. 2012). Sen sijaan rypsi- tai soijatäydennys tyypillisesti lisää lypsylehmien kuiva-aineen syöntiä nurmisäilörehupohjaisessa ruokinnassa (Huhtanen ym. 2011). Mikrolevistä lypsylehmien rehuna on vähän tutkimustietoa. Tässä tutkimuksessa selvitettiin mikrolevien vaikutusta lypsylehmien rehun syöntiin, ravintoaineiden sulavuuteen, maidontuotantoon ja maidon rasvahappokoostumukseen rypsiin ja soijaan verrattuna. Hypoteesina oli, että lypsylehmien kuiva-aineen syönti ja maitotuotos ovat pienempiä, kun valkuaistäydennyksenä on mikrolevä rypsin tai soijan sijaan.

\section{AINEISTOT JA MENETELMÄT}

Viikin opetus- ja tutkimustilan navetassa tehtiin samanaikaisesti kaksi ruokintakoetta. Kokeessa 1 oli 8 ay-lehmää, joiden poikimisesta oli kokeen alkaessa keskimäärin 186 pv. Koemallina oli toistettu 4x4 latinalainen neliö. Kontrolliruokinnassa lehmät saivat väkirehuna vilja-melassileikeseosta ilman valkuaislisää. Isonitrogeenisinä valkuaistäydennyksinä olivat rypsirouhe, Spirulina platensis-leväjauho tai näiden seos vastaten $2,5 \mathrm{~kg}: n$ rypsirouheannosta/pv. Väkirehuannos oli $12 \mathrm{~kg} / \mathrm{pv}$ sisältäen kivennäis- ja vitamiinilisän. Kokeessa 2 oli 4 ay-lehmää, joiden poikimisesta oli keskimäärin 112 pv. Koemallina oli 4x4 latinalainen neliö. Isonitrogeenisinä vilja-melassileikeseoksen valkuaistäydennyksinä olivat soijarouhe, Spirulina platensis, Chlorella vulgaris sekä Chlorella vulgariksen ja Nannochlorpsis gaditanan seos vastaten 1,8 kg:n soijarouheannosta/pv. Väkirehuannos oli $12,5 \mathrm{~kg} / \mathrm{pv}$ sisältäen kivennäis- ja vitamiinilisän. Molemmissa kokeissa väkirehut jaettiin viidesti päivässä (klo 6, 10.30, 14.30, 17, 19.30) ja lehmät saivat nurmiheinäsäilörehua vapaasti. Nurmisäilörehu oli korjattu 2. sadosta pyöröpaaleihin lyhyen esikuivauksen jälkeen käyttäen muurahaishappopohjaista säilöntäainetta (6 1/tn rehua, AIV 2 Plus, Kemira, Helsinki, Suomi). Rypsitiiviste ja soijatiiviste sisälsivät rypsi- ja soijarouheen lisäksi pieniä määriä melassileikettä ja seosmelassia, mikä kompensoitiin mikroleväruokinnoissa lisäämällä niitä väkirehun sekaan vastaava määrä. Vilja-melassileikeseos sekä rypsi- ja soijatiiviste olivat A-rehu Oy:n (Varkaus, Suomi), melassileike ja seosmelassi Hankkija Oy:n (Suomen rehu, Hyvinkää, Suomi) sekä kivennäis- ja vitamiiniseos Raisioagro Oy:n (Pihatto-Melli Plus, Raisio, Suomi) valmistamia. Mikrolevät hankittiin Duplaco B.V.:n (Hengalo, Alankomaat) kautta. Lehmät olivat kytkettyinä parsiin, jotka oli varustettu vaa'allisin RIC-rehukupein (Insentec B.V., Marknesse, Alankomaat). Lehmät lypsettiin kahdesti päivässä klo 6.00 ja 17.00 .

Koejaksojen kaksi ensimmäistä viikkoa olivat totutusviikkoja ja kolmas viikko keruuviikko. Keruuviikon aikana syötetyistä rehuista (koejakson päivät 15-21), sonnasta (17-20), maidosta (18-20), pötsinesteestä (20, koe 1) sekä häntäsuonen verestä (21) otettiin näytteet. Säilörehun ja väkirehun syönti sekä maitotuotos kirjattiin ylös päivittäin. Ravintoaineiden sulavuus laskettiin happoon liukenemattoman tuhkan (AIA) avulla. Rehut, sonta, pötsineste, plasma ja maidon peruskoostumus analysoitiin Ylisen (2015) kuvaamien menetelmien mukaan. Rehujen ja maidon rasvahapot analysoitiin kaasukromatografisesti 100 m CP-Sil 88-kolonnia (Chromopack 7489, Middelburg, Alankomaat) käyttäen (Stamm 2015).

Tulosten analysointiin käytettiin SAS-ohjelmiston (versio 9.3, SAS Institute Inc., Cary, Yhdysvallat) Mixed-proseduurin varianssianalyysiä. Kokeen 1 tilastollisessa mallissa kiinteinä muuttujina olivat koeruokinta, neliö ja jakson vaikutus neliössä sekä satunnaismuuttujana eläin neliössä. Kokeen 2 tilastollisessa mallissa kiinteinä muuttujina olivat koeruokinta ja jakso ja satunnaismuuttujana eläin. 


\section{TULOKSET JA TULOSTEN TARKASTELU}

Koerehujen koostumus on taulukossa 1. Kokeissa käytetty säilörehu oli säilönnälliseltä laadultaan hyvää. Se sisälsi kuitenkin suhteellisen vähän raakavalkuaista (135 g/kg kuiva-ainetta (ka)) ja sen D-arvo oli kohtalainen (656 g/kg ka). Spirulina ja Chlorella sisälsivät runsaasti raakavalkuaista. Nannochloropsiksen raakavalkuaispitoisuus oli muita mikroleviä pienempi sijoittuen rypsi- ja soijatiivisteiden väliin. Spirulina ja Chlorella eivät sisältäneet lainkaan neutraalidetergenttikuitua (NDF) ja myös Nannochloropsiksessa sitä oli vähän. Nannochloropsis sisälsi muita mikroleviä enemmän tuhkaa. Mikrolevien rasvahappopitoisuus oli suhteellisen pieni (29-33 g/ $/ \mathrm{kg} \mathrm{ka})$, mutta niiden rasvahappokoostumukset poikkesivat suuresti toisistaan. Spirulinan lipidien runsaimmat rasvahapot olivat 16:0, 18:2n-6 ja 18:3n6, Chlorellan 16:0, 16:2 ja 18:2n-6 ja Nannochloropsiksen 16:0, cis-9 16:1 ja 20:5n-3. Säilörehun lipidien runsain rasvahappo oli 18:3n-3, rypsin cis-9 18:1 ja soijan sekä vilja-melassileikeseoksen 18:2n-6.

Taulukko 1. Koerehujen koostumus

\begin{tabular}{|c|c|c|c|c|c|c|c|c|c|}
\hline & \multirow{2}{*}{$\begin{array}{l}\text { Säilö- } \\
\text { rehu }\end{array}$} & \multirow{2}{*}{$\begin{array}{c}\text { Vilja- } \\
\text { melassi- } \\
\text { leikeseos }\end{array}$} & \multirow{2}{*}{$\begin{array}{l}\text { Melassi- } \\
\text { leike }\end{array}$} & \multirow{2}{*}{$\begin{array}{l}\text { Seos- } \\
\text { melassi }\end{array}$} & \multirow{2}{*}{$\begin{array}{l}\text { Rypsi- } \\
\text { tiiviste }\end{array}$} & \multirow{2}{*}{$\begin{array}{c}\text { Soija- } \\
\text { tiiviste }\end{array}$} & \multicolumn{3}{|c|}{ Mikrolevät } \\
\hline & & & & & & & Spirulina & Chlorella & $\begin{array}{l}\text { Nanno- } \\
\text { chloropsis }\end{array}$ \\
\hline Kuiva-aine, g/kg & 377 & 900 & 879 & 706 & 866 & 878 & 946 & 948 & 962 \\
\hline \multicolumn{10}{|c|}{ Kuiva-aineessa, g/kg } \\
\hline Tuhka & 81,7 & 34,3 & 66,8 & 103 & 66,1 & 75,5 & 71,8 & 51,4 & 158 \\
\hline $\mathrm{NDF}^{2}$ & 496 & 362 & 339 & - & 272 & 145 & - & - & 76,8 \\
\hline Raakavalkuainen & 135 & 122 & 112 & 13,0 & 311 & 439 & 697 & 586 & 385 \\
\hline Rasvahapot & 15,8 & 25,2 & 5,51 & 1,08 & 25,2 & 9,86 & 28,8 & 33,1 & 28,9 \\
\hline \multicolumn{10}{|c|}{ Rasvahappokoostumus, g/100g } \\
\hline 14:0 & 0,72 & 0,20 & 0,21 & 1,17 & 0,17 & 0,13 & 0,16 & 0,06 & 3,00 \\
\hline $16: 0$ & 16,8 & 19,6 & 23,1 & 18,3 & 8,27 & 14,7 & 45,7 & 15,8 & 24,3 \\
\hline cis-9 16:1 & 0,24 & 0,14 & 0,27 & - & 0,90 & 0,16 & 2,76 & 0,49 & 35,6 \\
\hline $16: 2$ & - & - & - & - & - & - & - & 26,4 & - \\
\hline 18:0 & 2,02 & 1,40 & 0,73 & 3,59 & 2,65 & 2,95 & 1,05 & 0,16 & 0,72 \\
\hline cis-9 18:1 & 5,06 & 20,5 & 13,7 & 31,5 & 43,1 & 20,5 & 2,70 & 2,47 & 5,39 \\
\hline cis-11 18:1 & 0,70 & 0,98 & 1,39 & 1,29 & 9,23 & 2,22 & 0,62 & 0,74 & 0,59 \\
\hline $18: 2 n-6$ & 18,6 & 50,4 & 49,2 & 34,6 & 25,1 & 50,5 & 23,5 & 48,5 & 1,40 \\
\hline $18: 3 n-3$ & 48,0 & 4,93 & 8,78 & 7,81 & 8,05 & 7,45 & 0,37 & 2,31 & 0,03 \\
\hline $18: 3 n-6$ & - & 0,03 & - & - & 0,03 & - & 19,9 & 0,03 & 0,22 \\
\hline $20: 5 n-3$ & - & - & - & - & 0,04 & - & - & 0,02 & 19,2 \\
\hline
\end{tabular}

${ }^{1}$ Säilörehun käymislaatu (g/kg kuiva-ainetta): maitohappo 27,2 , etikkahappo 6,8 , propionihappo 0,8 , voihappo 0,2 ja vesiliukoiset hiilihydraatit 136, pH 4,24, ammoniumtyppi 19,6 g/kg N. D-arvo 656 g/kg kuiva-ainetta.

${ }^{2}$ Neutraalidetergenttikuitu

\section{Koe 1. Valkuaistäydennys sekä rypsirouheen korvaaminen Spirulinalla}

Valkuaistäydennys lisäsi suuntaa-antavasti $(\mathrm{P}<0,10)$ eläinten säilörehun syöntiä ja paransi $(\mathrm{P}<0,01)$ orgaanisen aineen ja NDF:n sulavuutta (Taulukko 2). Huhtasen ym. (2011) kirjallisuuskatsauksen ja metaanalyysin mukaan valkuaistäydennyksen (rypsi, soija) kuiva-aineen syöntiä lisäävä vaikutus johtuu todennäköisesti kuidun nopeammasta sulatuksesta pötsissä sekä käytettävissä olevien aminohappojen sekä energian tasapainoisemmasta suhteesta kudoksissa. Tässä kokeessa valkuaistäydennys lisäsi plasman välttämättömien aminohappojen pitoisuutta (Lamminen ym. 2016), mutta se ei vaikuttanut $(\mathrm{P}>0,10)$ plasman glukoosi- ja etikkahappopitoisuuksiin (keskimäärin 3,59 ja 1,54 mmol/l, vastaavasti, plasmadataa ei esitetty taulukoissa). Valkuaistäydennys lisäsi suuntaa-antavasti $(\mathrm{P}<0,10)$ energiakorjattua maitotuotosta (EKM) heijastaen lisäystä aminohappojen saannissa, säilörehun syönnissä ja ravintoaineiden sulavuudessa ja täten energian saannissa. Rypsirouheella saatu lisäys maitotuotokseen $(+1,99$ $\mathrm{kg}$ EKM per kg rypsin valkuaista) oli kuitenkin pieni verrattuna aikaisempiin tuloksiin (keskimäärin $+3,71 \mathrm{~kg}$ EKM per kg rypsin valkuaista, Huhtanen ym. 2011). Dieetin orgaanisen aineen ja NDF:n sulavuudet olivat tässä kokeessa suhteellisen alhaisella tasolla johtuen todennäköisesti säilörehun kohtalaisen pienestä D-arvosta. Täten energian saanti saattoi rajoittaa lisävalkuaisen täysimääräistä hyväksikäyttöä mikrobivalkuaisen sekä maidon tuotantoon tässä kokeessa. Huhtasen ym. (2011) mukaan ohutsuolesta imeytyvän valkuaisen (OIV) hyväksikäyttö paranee energian saannin lisääntyessä. 
Valkuaistäydennyksen sisältämät lipidit muuttivat jonkin verran maidon rasvahappokoostumusta. Ne vähensivät $(\mathrm{P}<0,001)$ maitorasvan monityydyttymättömien rasvahappojen 18:2n-6 ja 18:3n-3 pitoisuutta ja lisäsivät $(\mathrm{P}<0,10)$ biohydrogenaation välituotteiden (Shingfield ym. 2010) trans-11 18:1, cis9, trans-11 18:2 ja trans-11,cis-15 18:2 pitoisuuksia maitorasvassa. Vilja-melassileikeseoksen rasvahapoista suurin osa oli 18:2n-6:a ja sen osuus väkirehusta oli suurempi kontrolliruokinnassa kuin rypsiä ja Spirulinaa sisältävissä ruokinnoissa (väkirehun määrä tasattiin muuttamalla vilja-melassileikeseoksen osuutta koeväkirehuissa). Tämä selittää valkuaisruokintojen pienempää $(\mathrm{P}<0,001)$ 18:2n-6:n saantia ja maitorasvan 18:2n-6-pitoisuutta kontrolliruokintaan verrattuna. Sen sijaan 18:3n-3:n saanti oli suurempi $(\mathrm{P}<0,10)$, mutta pitoisuus maitorasvassa pienempi valkuais- kuin kontrolliruokinnassa. Alhaisen pötsin pH:n (alle 6) tiedetään vähentävän tyydyttymättömien rasvahappojen biohydrogenaatiota pötsissä (Troegeler-Meynadier ym. 2003) johtuen todennäköisesti muutoksista lipolyytisten ja biohydrogenoivien pötsimikrobien määrässä ja aktiivisuudessa (Fuentes ym. 2009). Pötsinesteen keskimääräisessä pH:ssa $(6,20)$ tai pötsinesteen $\mathrm{pH}$ :ssa eri näytteenottoaikoina (1,5 h välein alkaen klo 6 aamulla, $\mathrm{n}=8, \mathrm{pH}: \mathrm{n}$ vaihteluväli 5,69-6,90) ei kuitenkaan ollut eroa koeruokintojen välillä $(\mathrm{P}>0,10$, pötsikäymisdataa ei esitetty taulukossa). On kuitenkin mahdollista, että muutokset pötsin $\mathrm{pH}$ :ssa heti väkirehun jaon jälkeen olivat pienempiä ja hitaampia valkuaisruokinnoissa, joiden väkirehut sisälsivät vähemmän tärkkelystä ja enemmän valkuaista, kuin kontrolliruokinnassa. Väkirehun osuus dieetistä oli myös hieman pienempi valkuais- kuin kontrolliruokinnassa (44 vs. $47 \%$ kuiva-aineesta, $\mathrm{P}<0,05$ ).

Spirulina heikensi hieman väkirehun maittavuutta rypsiin verrattuna. Kun Spirulinan osuus väkirehun valkuaisesta lisääntyi, lehmät kompensoivat vähäisempää väkirehun syöntiään säilörehun syönnillä $(\mathrm{P}<0,05)$, joten koko dieetin kuiva-aineen syönneissä ei ollut eroa koeruokintojen välillä $(\mathrm{P}>0,10$, Taulukko 2). Rypsin korvaaminen Spirulinalla ei vaikuttanut $(\mathrm{P}>0,10)$ maitotuotokseen eikä maidon rasvapitoisuuteen tai -tuotokseen. Myöskään aikaisemmassa kokeessa, jossa rypsin valkuaista korvattiin asteittain Spirulina- ja Chlorella-levien seoksella, mikroleväruokinta ei vaikuttanut kuiva-aineen kokonaissyöntiin eikä maidon pitoisuuksiin (Ylinen 2015). Maitotuotos oli kuitenkin suuntaa-antavasti suurempi, kun leväseos korvasi puolet rypsistä puhtaaseen rypsi- tai levävalkuaisruokintaan verrattuna (Ylinen 2015). Kun Spirulinan osuus väkirehun valkuaisesta lisääntyi, maitorasvan 16:0- ja 18:3n-6pitoisuudet suurenivat lineaarisesti $(\mathrm{P}<0,001)$ heijastaen Spirulinan rasvahappokoostumusta. Vaikka cis-9 18:1 saanti pieneni lineaarisesti $(\mathrm{P}<0,001)$ Spirulinan korvatessa rypsiä, se ei vaikuttanut $(\mathrm{P}>0,10)$ maitorasvan cis-9 18:1-pitoisuuteen. Rypsin korvaaminen Spirulinalla kuitenkin vähensi lineaarisesti $(\mathrm{P}<0,01)$ maitorasvan 18:0-, trans-11 18:1- ja cis-9,trans-11 18:2-pitoisuutta. Tämä viittaa rypsin lipidien tehokkaaseen, osin epätäydelliseen biohydrogenaatioon pötsissä.

\section{Koe 2. Soijarouheen korvaaminen eri mikrolevillä}

Mikrolevät, etenkin Nannochloropsis, heikensivät väkirehun maittavuutta perinteisiin valkuaisrehuihin verrattuna. Tämä oli odotettavaa aikaisempien tutkimustulosten perusteella (Franklin ym. 1999, Drewery ym. 2012). Eläinkohtaiset erot mikrolevien maittavuudessa olivat kuitenkin suuria. Lehmät kompensoivat mikroleväruokinnoissa vähäisempää väkirehun syöntiä säilörehun syönnillä $(\mathrm{P}<0,10)$, joten koko dieetin kuiva-aineen syönneissä ei ollut eroa $(\mathrm{P}>0,10)$ koeruokintojen välillä (Taulukko 3$)$. Soijan korvaaminen mikrolevällä ei vaikuttanut $(\mathrm{P}>0,10)$ maitotuotokseen. Levälajien väliset erot maidontuotannossa olivat kuitenkin numeerisesti suuria. Energiakorjattu maitotuotos oli noin $4 \mathrm{~kg} / \mathrm{pv}$ suurempi Spirulina-ruokinnassa muihin ruokintoihin verrattuna. Soijan korvaaminen mikrolevällä lisäsi $(\mathrm{P}<0,10)$ etikkahapon pitoisuutta plasmassa ja sen ottoa maitorauhaseen $(\mathrm{P}<0,05$, plasmadataa ei esitetty taulukoissa) sekä maidon rasvapitoisuutta $(\mathrm{P}<0,10)$. Etikkahappo on yhdessä $\beta$-hydroksivoihapon kanssa maitorauhasen rasvahappojen synteesin esiaine. Spirulina-ruokinta lisäsi maidon rasvapitoisuutta $(\mathrm{P}<0,05)$ ja -tuotosta $(\mathrm{P}<0,10)$ Chlorella-ruokintoihin verrattuna. Tämä selittynee ainakin osittain plasman suuremmalla etikkahapon pitoisuudella $(2,6$ vs. $1,4 \mathrm{mmol} / \mathrm{l}, \mathrm{P}<0,01)$ ja etikkahapon suuremmalla otolla maitorauhaseen Spirulina-ruokinnassa Chlorella-ruokintoihin verrattuna (16 vs. $10 \mathrm{~mol} / \mathrm{pv}$, $\mathrm{P}<0,01)$. Erot mikrolevien rasvahappokoostumuksessa heijastuivat maitorasvaan. Spirulina lisäsi maitorasvan 18:3n-6-pitoisuutta ja Chlorella 18:2n-6-pitoisuutta. Nannochloropsiksen lisääminen Chlorella-ruokintaan kolminkertaisti maitorasvan EPA-pitoisuuden $(\mathrm{P}<0,05)$. Kaiken kaikkiaan muutokset maitorasvan koostumuksessa olivat kuitenkin melko pieniä (Taulukko 3), sillä tutkitut valkuaisrehut sisälsivät suhteellisen vähän lipidejä (Taulukko 1). 
Taulukko 2. Koe 1: syönti, sulavuus, maidontuotanto ja maidon koostumus

\begin{tabular}{|c|c|c|c|c|c|c|c|c|}
\hline & \multicolumn{4}{|c|}{ Koeruokinta } & \multirow[b]{2}{*}{ SEM } & \multicolumn{3}{|c|}{$P$-arvo ${ }^{1}$} \\
\hline & Kontrolli & Rypsi & $\begin{array}{l}\text { Rypsi + } \\
\text { Spirulina }\end{array}$ & Spirulina & & $\begin{array}{l}\text { Valkuais- } \\
\text { lisä }\end{array}$ & $\begin{array}{c}\text { Spirulina } \\
\text { lineaarinen }\end{array}$ & $\begin{array}{r}\text { Spirulina } \\
\text { 2. aste } \\
\end{array}$ \\
\hline \multicolumn{9}{|l|}{ Syönti, kg/pv } \\
\hline Säilörehun kuiva-aine & 12,2 & 12,9 & 12,8 & 13,3 & 0,57 & o & & \\
\hline Dieetin kuiva-aine & 22,8 & 23,4 & 23,0 & 22,8 & 0,49 & & & \\
\hline Orgaaninen aine & 21,2 & 21,6 & 21,3 & 21,2 & 0,45 & & & \\
\hline Neutraalidetergenttikuitu & 9,61 & 9,66 & 9,44 & 9,36 & 0,244 & & & \\
\hline $16: 0, \mathrm{~g} / \mathrm{pv}$ & 82,0 & 76,1 & 82,4 & 87,4 & 1,27 & & $* * *$ & \\
\hline cis-9 18:1, g/pv & 62,7 & 76,9 & 65,4 & 52,9 & 0,76 & $*$ & $* * *$ & \\
\hline cis-11 18:1, g/pv & 3,51 & 8,84 & 6,02 & 3,32 & 0,057 & $* * *$ & $* * *$ & \\
\hline $18: 2 n-6, g / p v$ & 165 & 150 & 150 & 147 & 1,91 & $* * *$ & & \\
\hline $18: 3 n-3, g / p v$ & 98,4 & 105 & 102 & 104 & 3,9 & o & & \\
\hline $18: 3 n-6, g / p v$ & 0,08 & 0,08 & 3,17 & 5,83 & 0,118 & $* * *$ & $* * *$ & \\
\hline Rasvahapot, g/pv & 441 & 449 & 441 & 432 & 7,1 & & $*$ & \\
\hline \multicolumn{9}{|c|}{ Syödyn dieetin koostumus, $\mathrm{g} / \mathrm{kg}$ kuiva-ainetta } \\
\hline Väkirehun osuus dieetissä & 466 & 451 & 449 & 422 & 15,2 & $*$ & $*$ & \\
\hline Orgaaninen aine & 930 & 926 & 926 & 927 & 0,3 & $* * *$ & $* *$ & \\
\hline Raakavalkuainen & 125 & 146 & 149 & 151 & 0,6 & $* * *$ & $* * *$ & \\
\hline Neutraalidetergenttikuitu & 421 & 413 & 409 & 409 & 2,4 & $* * *$ & & \\
\hline \multicolumn{9}{|l|}{ Sulavuus, $\mathrm{g} / \mathrm{kg}$} \\
\hline Orgaaninen aine & 646 & 660 & 657 & 661 & 5,5 & $* *$ & & \\
\hline Neutraalidetergenttikuitu & 441 & 481 & 475 & 494 & 11,3 & $* * *$ & & \\
\hline \multicolumn{9}{|l|}{ Tuotos ja maidon pitoisuudet } \\
\hline Maito, kg/pv & 26,7 & 28,0 & 27,3 & 27,3 & 1,02 & & & \\
\hline $\mathrm{EKM}^{2}, \mathrm{~kg} / \mathrm{pv}$ & 28,7 & 30,3 & 29,1 & 29,6 & 1,39 & o & & \\
\hline Rasva, g/pv & 1230 & 1299 & 1258 & 1288 & 75,1 & & & \\
\hline Laktoosi, g/pv & 1109 & 1178 & 1123 & 1132 & 56,2 & & & \\
\hline Valkuainen, $\mathrm{g} / \mathrm{pv}$ & 999 & 1045 & 997 & 1002 & 31,5 & & o & \\
\hline Rasva, g/kg & 46,2 & 46,5 & 45,8 & 46,9 & 1,83 & & & \\
\hline Laktoosi, $\mathrm{g} / \mathrm{kg}$ & 41,4 & 41,9 & 40,7 & 41,2 & 0,74 & & & $\mathrm{o}$ \\
\hline Valkuainen, $\mathrm{g} / \mathrm{kg}$ & 37,5 & 37,5 & 36,7 & 36,9 & 0,83 & & & \\
\hline $\begin{array}{l}\text { EKM }{ }^{2}, \mathrm{~kg} / \text { kuiva-aineen } \\
\text { syönti, } \mathrm{kg}\end{array}$ & 1,26 & 1,29 & 1,25 & 1,29 & 0,52 & & & $*$ \\
\hline \multicolumn{9}{|l|}{ Maidon rasvahapot, g/100g } \\
\hline $4: 0$ & 3,58 & 3,56 & 3,64 & 3,68 & 0,048 & & $*$ & \\
\hline $6: 0$ & 2,41 & 2,40 & 2,42 & 2,42 & 0,041 & & & \\
\hline $8: 0$ & 1,60 & 1,55 & 1,54 & 1,52 & 0,051 & & & \\
\hline 10:0 & 3,47 & 3,57 & 3,56 & 3,42 & 0,077 & & & \\
\hline $12: 0$ & 3,90 & 4,14 & 4,10 & 3,96 & 0,084 & & & \\
\hline $14: 0$ & 11,8 & 12,1 & 12,0 & 12,0 & 0,14 & & & \\
\hline $16: 0$ & 28,5 & 27,5 & 28,4 & 29,5 & 0,55 & & $* * *$ & \\
\hline cis-9 16:1 & 0,94 & 0,92 & 0,96 & 1,09 & 0,039 & & $* * *$ & \\
\hline 18:0 & 11,6 & 11,6 & 11,5 & 10,7 & 0,35 & & $* *$ & \\
\hline cis-9 18:1 + trans-15 18:1 & 17,3 & 17,4 & 17,0 & 17,0 & 0,45 & & & \\
\hline cis-11 18:1 & 0,39 & 0,53 & 0,46 & 0,41 & 0,019 & $* *$ & $* * *$ & \\
\hline trans-10 18:1 & 0,23 & 0,23 & 0,21 & 0,21 & 0,010 & & & \\
\hline trans-11 18:1 & 1,10 & 1,35 & 1,25 & 1,17 & 0,065 & $* * *$ & $* * *$ & \\
\hline $18: 2 n-6$ & 2,41 & 1,95 & 2,02 & 1,90 & 0,118 & $* * *$ & & \\
\hline cis-9,trans-11 18:2 & 0,36 & 0,57 & 0,51 & 0,51 & 0,028 & $* * *$ & $* * *$ & $*$ \\
\hline trans-11,cis-15 18:2 & 0,14 & 0,16 & 0,15 & 0,16 & 0,012 & o & & o \\
\hline $18: 3 n-3$ & 0,54 & 0,51 & 0,50 & 0,49 & 0,002 & $* * *$ & o & \\
\hline $18: 3 n-6$ & 0,04 & 0,03 & 0,05 & 0,06 & 0,003 & $* * *$ & $* * *$ & \\
\hline Tyydyttyneet & 71,0 & 70,7 & 71,5 & 71,5 & 0,70 & & & \\
\hline Kertatyydyttymättömät & 24,0 & 24,5 & 23,8 & 23,9 & 0,55 & & & \\
\hline Monityydyttymättömät & 3,95 & 3,57 & 3,59 & 3,50 & 0,167 & $* * *$ & & \\
\hline
\end{tabular}

${ }^{1}$ Valkuaislisän sekä rypsirouheen valkuaisen korvaaminen Spirulinan valkuaisella lineaarinen ja 2. asteen tilastollinen merkitsevyys $* * *(\mathrm{P}<0,001), * *(\mathrm{P}<0,01), *(\mathrm{P}<0,05)$ ja $\mathrm{o}(\mathrm{P}<0,10)$

${ }^{2}$ Energia korjattu maitotuotos 
Taulukko 3, Koe 2: syönti, sulavuus, maidontuotanto ja maidon koostumus

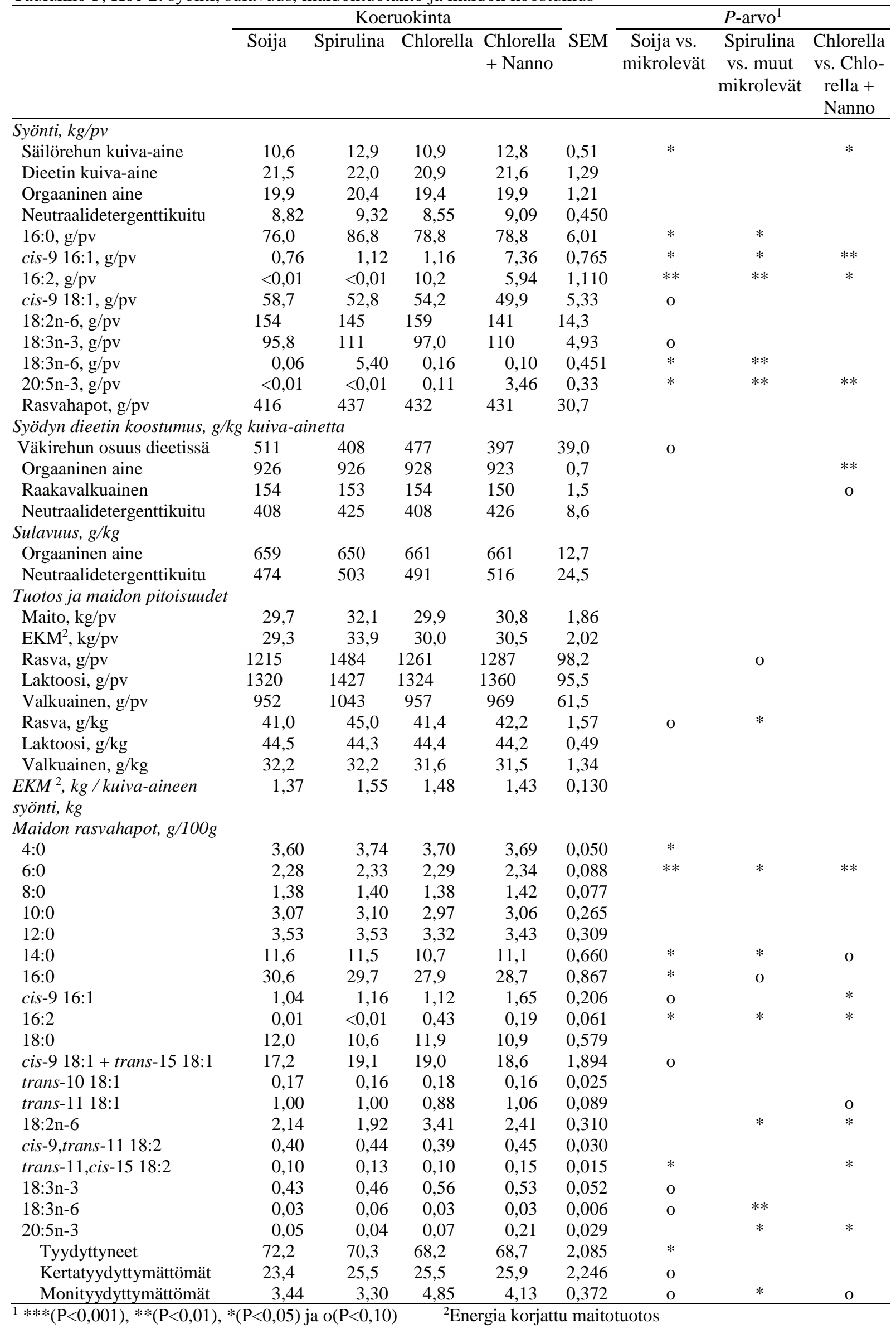




\section{JOHTOPÄÄTÖKSET}

Tulosten perusteella mikrolevien maidontuotanto-ominaisuudet vastaavat soijarouhetta lypsylehmien vilja-nurmisäilörehupohjaisessa ruokinnassa. Mikrolevistä Spirulinan maidontuotanto-ominaisuudet saattavat olla jopa soijarouhetta hieman paremmat vastaten lähes rypsirouhetta. Huono maittavuus voi kuitenkin vähentää yksittäisten eläinten mikroleväjauhon syöntiä etenkin, jos mikrolevä sisältää runsaasti pitkäketjuisia (20-hiilisiä), monityydyttymättömiä rasvahappoja. Tutkituista mikrolevistä Spirulina lisäsi maitorasvan 18:3n-6-pitoisuutta, Chlorella 18:2n-6-pitoisuutta ja Nannochloropsis EPA-pitoisuutta, joskin muutokset olivat melko pieniä.

\section{KIRJALLISUUS}

Becker, E.W. 2007. Micro-algae as a source of protein. Biotechnology Advances 25:207-210.

Drewery, M.L., Sawyer, J.E. \& Wickersham, T.A. 2012. Palatability of post-extraction algal residue as a protein supplement for cattle. Journal of Dairy Science 95(Suppl. 2):342. http://www.jtmtg.org/JAM/2012/abstracts.asp Viitattu 3.12.2015.

Franklin S.T., Martin, K.R., Baer, R.J., Schingoethe, D.J. \& Hippen, A.R. 1999. Dietary marine algae (Schizochytrium sp.) increases concentrations of conjugated linoleic, docosahexaenoic and transvaccenic acids in milk of dairy cows. The Journal of Nutrition 129:2048-2054.

Fuentes, M.C., Calsamiglia, S., Cardozo, P.W. \& Vlaeminck, B. 2009. Effect of pH and level of concentrate in the diet on the production of biohydrogenation intermediates in a dual-flow continuous culture. Journal of Dairy Science 92:4456-4466.

Huhtanen, P., Hetta, M. \& Swensson, C. 2011. Evaluation of canola meal as a protein supplement for dairy cows: A review and a meta-analysis. Canadian Journal of Animal Science 91:529-543.

Huhtanen, P., Vanhatalo A. \& Varvikko, T. 2002. Effects of abomasal infusions of histidine, glucose, and leucine on milk production and plasma metabolites of dairy cows fed grass silage diets. Journal of Dairy Science 85:204-216.

Lamminen, M., Halmemies-Beauchet-Filleau, A., Kokkonen, T., Jaakkola, S. \& Vanhatalo, A. 2016. Mikrolevät lypsylehmien ruokinnassa: 2. Valkuaisen hyväksikäyttö. Maataloustieteen Päivät 2016. www.smts.fi Lang, I., Hodac, L., Friedl, T. \& Feussner, I. 2011. Fatty acid profiles and their distribution patterns in microalgae: a comprehensive analysis of more than 2000 strains from the SAG culture collection. BMC Plant Biology 11:124-140.

Mata, T,M., Martins, A.A. \& Caetano, N.S. 2010. Microalgae for biodiesel production and other applications: A review. Renewable and Sustainable Energy Reviews 14:217-232.

Luke 2015. Rehutaulukot ja ruokintasuositukset. Verkkojulkaisu. https://portal.mtt.fi/portal/page/portal/Rehutaulukot Viitattu 3.12.2015.

Shingfield, K.J., Bernard, L., Leroux, C. \& Chilliard, Y. 2010. Role of trans fatty acids in the nutritional regulation of mammary lipogenesis in ruminants. Animal 4:1140-1166.

Stamm, M. 2015. Effects of different microalgae supplements on fatty acid composition, oxidation stability, milk fat globule size and phospholipid content of bovine milk. Maisterin tutkielma. Helsingin yliopisto, Elintarvike- ja ympäristötieteiden laitos. 86s. http://urn.fi/URN:NBN:fi:hulib-201510193736

Troegeler-Meynadier, A., Nicot, M.C., Bayourthe, C., Moncoulon, R. \& Enjalbert, F. 2003. Effects of pH and concentrations of linoleic and linolenic acids on extent and intermediates of ruminal biohydrogenation in vitro. Journal of Dairy Science 86:4054-4063.

Vanhatalo, A., Huhtanen, P., Toivonen, V. \& Varvikko, T. 1999. Response of dairy cows fed grass silage diets to abomasal infusions of histidine alone or in combinations with methionine and lysine. Journal of Dairy Science 82:2674-2685.

Ylinen, V. 2015. Mikrolevä lypsylehmien valkuaisrehuna - vaikutus syöntiin, aineenvaihduntaan ja maidontuotantoon. Maisterin tutkielma. Helsingin yliopisto, Maataloustieteiden laitos. 63s. 